\title{
Age and Weight Loss After Bariatric Surgery: Cause or Consequence?
}

\author{
Comment on Contreras JE, Santander C, Court I, Bravo J. Correlation Between Age \\ And Weight Loss After Bariatric Surgery. Obesity Surgery 2013; 23(8):1286-9
}

\author{
Gil Faria • Diogo Pestana • John Preto • João T. Guimarães • \\ António Taveira-Gomes • Conceição Calhau
}

Published online: 7 March 2014

(C) Springer Science+Business Media New York 2014

In spite of its indisputable role in the treatment of obesity, bariatric surgery is not absent of cutbacks and complications. Cumulative experience is allowing the discovery of factors associated with weight loss after bariatric surgery [1], which may allow the development of more selective and effective interventions. In this regard, both Contreras et al. [2] and Scozzari et al. [3] reports bring an important contribution, by clearly showing that patients' age negatively associates with success in weight loss. In the discussion of their results, the authors consider a range of facts possibly interfering with weight loss in people of more advanced age: from differences in energy requirements to social and psychological aspects and, probably of great importance, an impaired metabolic capacity and a lower lipolytic activity.

Results obtained by our group [4], in a sample of 163 obese patients, showed that, in good agreement with the results of Scozzari et al., younger patients $(<50$ years $)$ achieved a greater weight loss after 12 months of followup $(80 \%$ excess weight loss (EWL) vs $70 \%$ EWL; $p=$ 0.01 ). More interestingly, in the preoperative period and in comparison with older patients, younger (and most responsive) patients had significantly lower fasting glucose levels (93 vs $111 \mathrm{mg} / \mathrm{dL} ; p<0.001$ ) [4] and were less contaminated with persistent organic pollutants (POPs) in visceral adipose tissue $(168.9 \pm 13.7 \mathrm{ng} / \mathrm{g}$ of fat vs $311.0 \pm 32.7 \mathrm{ng} /$ $\mathrm{g}$ of fat, $p<0.0001)$ [POPs data to be published]. Specifically in our analysis, the effect of age disappeared after adjustment for fasting blood glucose levels.
As both higher fasting glucose [5] levels and higher levels of POPs [6] in adipose tissue will decrease lipolysis, this seems to be a most important mechanism behind the difficulty of older people to respond to weight-losing interventions. It would be interesting to study the influence of age on weight loss by other interventions and to further evaluate the capacity of fasting glucose and POPs levels to predict weight loss independently of age.

Conflicts of Interest The authors have no conflicts of interest to disclose.

\section{References}

1. Ortega E, Morínigo R, Flores L, et al. Predictive factors of excess body weight loss 1 year after laparoscopic bariatric surgery. Surg Endosc. 2012;26(6):1744-50.

2. Contreras JE, Santander C, Court I, et al. Correlation between age and weight loss after bariatric surgery. Obes Surg. 2013;23(8):1286-9.

3. Scozzari G, Passera R, Benvenga R, et al. Age as a long-term prognostic factor in bariatric surgery. Ann Surg. 2012;256(5):724-9.

4. Faria G, Preto J, Almeida AB, Guimarães JT. Fasting glycemia: a good predictor of weight loss after RYGB. Surgery for Obesity and Related Diseases 2013;

5. Mclaughlin T, Yee G, Glassford A, et al. Use of a two-stage insulin infusion study to assess the relationship between insulin suppression of lipolysis and insulin-mediated glucose uptake in overweight/obese, nondiabetic women. Metab, Clin Exp. 2011;60(12):1741-7.

6. Irigaray $\mathrm{P}$, Ogier $\mathrm{V}$, Jacquenet $\mathrm{S}$, et al. Benzo[a]pyrene impairs betaadrenergic stimulation of adipose tissue lipolysis and causes weight gain in mice. A novel molecular mechanism of toxicity for a common food pollutant. FEBS J. 2006;273(7):1362-72.

G. Faria $(\bowtie) \cdot$ D. Pestana $\cdot$ J. Preto $\cdot$ J. T. Guimarães

A. Taveira-Gomes $\cdot$ C. Calhau

Faculty of Medicine, University of Porto, Porto, Portugal

e-mail: gilrfaria@gmail.com 